\title{
The Extent to which Managers in Jordanian Private Hospitals Perceive the Importance of Marketing Knowledge
}

\author{
Hashem $\mathrm{TN}^{1 *}$ and Suleiman $0^{2}$ \\ ${ }^{1}$ Department of Marketing, Isra University, Jordan \\ ${ }^{2}$ The World Islamic Sciences and Education University, Jordan \\ *Corresponding author: Tareq N Hashem, Department of Marketing, Isra University \\ , Amman, Jordan, Tel: +962-6-5161652; Email: tareqhashem1975@yahoo.com
}

\section{Research Article \\ Volume 2 Issue 5}

Received Date: September 05, 2019

Published Date: September 16, 2019

DOI: $10.23880 /$ jqhe- 16000137

\section{Abstract}

This study aimed at identifying the extent to which managers in Jordanian private hospitals recognize the importance of marketing knowledge. The population consisted of managers in the Jordanian private hospitals. A convenience sample was selected from 60 managers, 40 questionnaires were returned for analysis, representing $66.67 \%$ of the sample size. By using Spssv23 program, several results were concluded. For instance, by using one sample t-test, it was found that there is a high level of awareness among managers in Jordanian private hospitals toward the importance of marketing knowledge and its dimensions (knowledge of patients, knowledge of health services and knowledge of competitors). The researchers recommended that the managers in hospitals must understand the marketing knowledge and should be aware of applying its dimensions in such a way as to gain strength to face competition in the local or forgien market.

Keywords: Marketing Knowledge; Knowledge of Patients; Knowledge of Health Services; Knowledge of Competitors

\section{Introduction}

The twenty-first century is characterized by comprehensive changes that resulted in many challenges facing different organizations, especially in the fields of globalization and competitiveness, the revolution of communications, information technology, the Internet, etc. This has been accompanied by significant implications in the pursuit of these developments in improving the efficiency and effectiveness of the performance of many organizations.

This development and implementation has contributed to the emergence of the importance of marketing knowledge and the emergence of a clear impact on the effectiveness of decision-making and the need to embark on the adoption of a targeted means to achieve and improve the efficiency and effectiveness of performance in particular [1].

Marketing knowledge plays an important and vital role in supporting the activities of organizations in various sectors including the health sector. Today, modern organizations view knowledge as an effective basis for creativity, innovation and development. Modern organizations are constantly striving to achieve efficiency and effectiveness and achieve outstanding performance, and for that purpose organizations are constantly developing their goals and products that satisfy the needs and desires of consumers in the target markets. Organizations must gain renewable knowledge and build high-value intellectual capital that gives organizations a significant competitive advantage in the knowledge economy [2]. 


\section{Journal of Quality in Health Care \& Economics}

The health sector does not differ from other sectors in terms of its interest for the beneficiaries of the services, which makes it important to conduct this study to identify the extent to which managers in Jordanian private hospitals recognize the importance of marketing knowledge.

\section{Problem of the Study}

Jordanian private hospitals do not live in isolation from the changes that occur in the needs of the beneficiaries of their services, and therefore are invited to expedite to take advantage of the marketing knowledge obtained in line with the developments and challenges of the times and contribute to raise the level of marketing performance. The previous studies lacked a study focused on the marketing knowledge in the health sector in general and hospitals in particular; hence the problem of the study could be summarized in the following question: What is the extent to which managers in Jordanian private hospitals recognize the importance of marketing knowledge?

\section{Theoretical Framework}

What is meant by Knowledge?: Knowledge is the most important strategic resource for the organization, and many managers believe that strategic advantages will be achieved by having more knowledge than competitors. The importance of knowledge makes it clear that organizations are better able to deal with organizational problems and opportunities [3]. And it is a source of competitive advantage that has become knowledge-based [4].

Organizations' micro-knowledge transformation quickly created a broad movement of macro knowledgebased transformation, and knowledge management became the prerequisite for all organizations. This shift has also led to talk about industrial and service organizations as knowledge-intensive organizations, and universities as knowledge-based institutions [5]. This development revealed the need for organizations to manage knowledge and the resulting marketing knowledge in order to create, share and use knowledge in the organization's products, services and processes and gain competitive advantage in the market.

Taylor, et al. [6] defined the characteristics of knowledge as being present in the minds of individuals by experience, formed as a result of learning.

It is noted from these characteristics that they include all types of knowledge in the organization and its operations and its effects on the organization management at different levels.

Marketing Knowledge: It is a full knowledge of the needs of customers should be included the preferences of the market and the factors of attraction [7]. Also Marketing Knowledge is all knowledge of marketing affairs in the organization, especially knowledge of products, markets, customers and competitors as well as practices of past marketing efforts in introducing new products [8]. Also it is one of the organization's skills in acquiring, creating, retaining and sharing knowledge based on the organization's view of its marketing environment $[8,9]$.

There are seven types of marketing knowledge that companies should be interested in: Knowledge of the consumer, Knowledge of products, Knowledge of competitors, Knowledge of marketing services provided, Knowledge of the procedures and systems followed by the company, Knowledge of topics that the company is currently interested, Knowledge of the individuals with whom the company deals inside and outside $[2,10]$.

Marketing knowledge enables the company to better identify existing customers and more accurately target non-existent clients, for example, in addition, marketing knowledge must provide companies with a better understanding of the potential environment of the company, which could anticipate the needs of the company.

For the purpose of the study the researchers concentrated on three types of Marketing Knowledge mentioned by Hashem, et al [2] Hanvanich, et al. [10] and can be used in the Health sector, these marketing knowledge dimensions are: Knowledge of patients, Knowledge of health services and Knowledge of competitors.

Study Hypotheses: After reviewing the theoretical literature, the researchers suggested the following hypotheses of the

> H1: There is a high level of awareness among managers in Jordanian private hospitals toward the importance of marketing knowledge.

$>$ H2: There is a high level of awareness among managers in Jordanian private hospitals toward the importance of knowledge of patients.

> H3: There is a high level of awareness among managers in Jordanian private hospitals toward the importance of knowledge of health services. 


\section{Journal of Quality in Health Care \& Economics}

H4: There is a high level of awareness among managers in Jordanian private hospitals toward the importance of knowledge of competitors.

Research Methodology: This study relies on the descriptive and analytical approach by reviewing the theoretical literature related to the study variables, in addition to applying the study tool for data collection, and reaching results that contribute to a set of recommendations [11].

Study Population and Sample: The study population consisted of managers in the Jordanian private hospitals. A convenience sample was selected from 60 managers. It takes a long time for collecting 40 questionnaires only, which represents $66.67 \%$ of the sample size.

Data Collection Methods: The study is based on two types of data: primary and secondary data, where secondary data are theoretical and field studies and previous books and research related to the subject under study. The primary data was collected by a questionnaire developed for hypotheses testing. The questionnaire included two main sections, including the personal data of the participants (gender, age, educational qualification, and years of experience), while the second section included 15 paragraphs measuring the variables of the study. The five-point Likert scale was used to measure the variables of the study (Table 1).

\begin{tabular}{|c|c|c|c|c|}
\hline $\begin{array}{c}\text { Strongly } \\
\text { Agree }\end{array}$ & Agree & Neutral & Disagree & $\begin{array}{c}\text { Strongly } \\
\text { Disagree }\end{array}$ \\
\hline 5 & 4 & 3 & 2 & 1 \\
\hline
\end{tabular}

Table 1: The scale of the questionnaire.

Validity and Reliability of the Scale: The apparent validity of the scale has been tested by presenting the questionnaire to a number of marketing arbitrators.

Cronbach's alpha test was used to measure the stability of the measuring instrument, where the value of $\alpha$ for the questionnaire as a whole was $89.3 \%$. , which is good because it is greater than accepted value 0.60 [12].

Sample Characteristics: It was found that the largest percentage of the sample of the study is male, the largest percentage of the sample is between the ages of 40-50 years, and the largest percentage of the sample has Bachelor degree with experience ranging from 10-15 years.

Descriptive Statistics: The mean and standard deviation of the variables were extracted from the following table 2 .

\begin{tabular}{|c|c|c|c|c|c|}
\hline & $\mathbf{N}$ & Minimum & Maximum & Mean & Std. Deviation \\
\hline Knowledge of patients & 40 & 2.6 & 5 & 4.03 & 0.76131 \\
\hline Knowledge of health services & 40 & 2.2 & 5 & 3.815 & 0.73643 \\
\hline Knowledge of competitors & 40 & 2.8 & 5 & 4.065 & 0.65066 \\
\hline Marketing knowledge & 40 & 2.8 & 5 & 3.97 & 0.64104 \\
\hline
\end{tabular}

Table 2: Descriptive Statistics.

The above table indicates that the sample attitudes are positive towards the above variables because their mean is greater than the cutoff point (3: it is the Neutral answer in the scale) the grand mean=3.97 indicates high level of awareness of marketing knowledge. Also it is found that knowledge of competitors has the highest mean, which indicates the highest level of awareness, whereas knowledge of health services has the lowest mean, which indicates the lowest level of awareness $[13,14]$.

Hypothesis Testing: H1: There is a high level of awareness among managers in Jordanian private hospitals toward the importance of marketing knowledge (Table 3).

\begin{tabular}{|c|c|c|c|c|}
\hline \multicolumn{5}{|c|}{ One-Sample Statistics } \\
\hline & $\mathbf{N}$ & Mean & Std. Deviation & Std. Error Mean \\
\hline H1 & 40 & 3.97 & 0.64104 & 0.10136 \\
\hline
\end{tabular}

\begin{tabular}{|c|c|c|c|c|c|c|}
\hline \multicolumn{9}{|c|}{ One-Sample Test } \\
\hline & t & df & Sig. (2-tailed) & Mean Difference & 95\% Confidence Interval of the Difference \\
\hline & & & & & Lower & Upper \\
\hline H1 & 9.57 & 39 & 0 & 0.97 & 0.765 & 1.175 \\
\hline
\end{tabular}

Table 3: H1 test. 
One sample T-test was used and it is found that the value of $(t=9.57)$ is significant at $(0.05)$, which means that there is a high level of awareness among managers in Jordanian private hospitals toward the importance of marketing knowledge.
H2: There is a high level of awareness among managers in Jordanian private hospitals toward the importance of knowledge of patients (Table 4).

\begin{tabular}{|c|c|c|c|c|}
\hline \multicolumn{5}{|c|}{ One-Sample Statistics } \\
\hline & N & Mean & Std. Deviation & Std. Error Mean \\
\hline H2 & 40 & 4.03 & 0.76131 & 0.12037 \\
\hline
\end{tabular}

\begin{tabular}{|c|c|c|c|c|c|c|}
\hline \multicolumn{9}{|c|}{ One-Sample Test } \\
\hline & t & df & Sig. (2-tailed) & Mean Difference & \multicolumn{2}{c|}{ 95\% Confidence Interval of the Difference } \\
\hline & & & & & Lower & Upper \\
\hline H2 & 8.6 & 39 & 0 & 1.03 & 0.7865 & 1.2735 \\
\hline
\end{tabular}

Table 4: H2 test.

One sample T-test was used and it is found that the value of $(t=8.557)$ is significant at $(0.05)$, which means that there is a high level of awareness among managers in Jordanian private hospitals toward the importance of knowledge of patients.
H3: There is a high level of awareness among managers in Jordanian private hospitals toward the importance of knowledge of health services (Table 5).

\begin{tabular}{|c|c|c|c|c|}
\hline \multicolumn{5}{|c|}{ One-Sample Statistics } \\
\hline & $\mathbf{N}$ & Mean & Std. Deviation & Std. Error Mean \\
\hline H3 & 40 & 3.815 & 0.73643 & 0.11644 \\
\hline
\end{tabular}

\begin{tabular}{|c|c|c|c|c|c|c|}
\hline \multicolumn{7}{|c|}{ One-Sample Test } \\
\hline \multicolumn{7}{|c|}{ Test Value $=3$} \\
\hline & $\mathbf{t}$ & df & Sig. (2-tailed) & Mean Difference & \multicolumn{2}{|c|}{ 95\% Confidence Interval of the Difference } \\
\hline & $\mathbf{t}$ & df & Sig. (2-tailed) & Difference & Lower & Upper \\
\hline H3 & 6.999 & 39 & 0 & 0.815 & 0.5795 & 1.0505 \\
\hline
\end{tabular}

Table 5: H3 test.

One sample T-test was used and it is found that the value of $(t=6.999)$ is significant at $(0.05)$, which means that there is a high level of awareness among managers in Jordanian private hospitals toward the importance of knowledge of health services.
H4: There is a high level of awareness among managers in Jordanian private hospitals toward the importance of knowledge of competitors (Table 6).

\begin{tabular}{|c|c|c|c|c|}
\hline \multicolumn{5}{|c|}{ One-Sample Statistics } \\
\hline & $\mathbf{N}$ & Mean & Std. Deviation & Std. Error Mean \\
\hline H4 & 40 & 4.065 & 0.65066 & 0.10288 \\
\hline
\end{tabular}

\begin{tabular}{|c|c|c|c|c|c|c|}
\hline \multicolumn{9}{|c|}{ One-Sample Test } \\
\hline & $\mathbf{t}$ & df & Sig. (2-tailed) & Mean Difference & \multicolumn{2}{c|}{ 95\% Confidence Interval of the Difference } \\
\hline & & & & & Lower & Upper \\
\hline H4 & 10.352 & 39 & 0 & 1.065 & 0.8569 & 1.2731 \\
\hline
\end{tabular}

Table 6: $\mathrm{H} 4$ test. 


\section{Journal of Quality in Health Care \& Economics}

One sample T-test was used and it is found that the value of $(t=10.352)$ is significant at $(0.05)$, which means that there is a high level of awareness among managers in Jordanian private hospitals toward the importance of knowledge of competitors.

\section{Results}

\section{Following Results were Found:}

1. There is a high level of awareness among managers in Jordanian private hospitals toward the importance of marketing knowledge.

2. There is a high level of awareness among managers in Jordanian private hospitals toward the importance of knowledge of patients.

3. There is a high level of awareness among managers in Jordanian private hospitals toward the importance of knowledge of health services.

4. There is a high level of awareness among managers in Jordanian private hospitals toward the importance of knowledge of competitors.

5. Marketing knowledge plays an important role in the success of the hospital and its continuity in the market through the promotion of work in its dimensions (knowledge of patients, knowledge of health services, and knowledge of competitors).

6. Positive mental status contributes to highlight good impressions and strengthen the link between the patient and the health service and the hospital and thus achieve success and superiority over competitors.

\section{Conclusion and Recommendations}

Hospitals in Jordan must have comprehensive knowledge about their patients and their competitors. Acquiring accurate information is a critical first step in achieving market success and in developing a marketing plan. The effects of health market trends, attitudes and characteristics of hospital activities will determine the success or failure of work. When hospitals begin to develop the market plan, they should focus on understanding the competitiveness of the market, as well as identifying the needs and desires of the clients. Hospitals that use marketing knowledge properly will be able to better understand their customers and thus maintain their loyalty.

\section{The Researchers Suggested the Following Recommendations:}

In order to adopt a successful and effective marketing strategy, the managers in hospitals must understand the marketing knowledge and should be aware of applying its dimensions in such a way as to gain strength to face competition in the local or forgien market.

$>$ The management of each hospital should conduct distinct training courses that increase the skill and experience of its staff and the exploitation of the possibilities and energies have in order to reach its objectives in the best way.

The need to increase interest in investing marketing knowledge in Jordanian hospitals in order to enhance their mental standing among the beneficiaries and find a competitive advantage through which they can achieve a better market share.

$>$ Increase attention and focus on exploiting the hospital culture to support the acquisition of knowledge and management so as to understand the experiences of others and try to meet the desire of current and potential beneficiaries to increase market share and find a marketing mix that suits the desire of the patient.

$>$ Conduct future studies dealing with marketing knowledge in the health sector in Jordan

\section{References}

1. Hashem T, Al Saadi B, Al DuwairiR, Irsheidat R (2014) The level of awareness managers in Jordanian industrial corporations enjoy regarding organizational memory in marketing knowledge management, The $8^{\text {th }}$ conference "Contemporary Business Environment Strategies: Novel Visions and ever-Changing Ideas" (29-30 April 2014) Philadelphia University Jordan.

2. Hashem $\mathrm{T}$ (2016) The Impact of Organizational Memory use in Marketing Knowledge Management on Marketing Audits in Jordanian Industrial Corporations. Global Journal of Emerging Trends in eBusiness, Marketing and Consumer Psychology (GJETeMCP) An Online International Research Journal 2(1): 337-350.

3. Turban Efraim, Pollard C, Wood G (2002) Information Technology For Management: On-Demand Strategies for Performance, Growth and Sustainability. 11 (Edn.), John Wiley \&Sons, Inc Danvers pp: 480.

4. Waltz Edward (2003) Knowledge Management, Artech House, Boston.

5. Geiger L (2004) Knowledge and Money, Stanford University Press, Stanford. 


\section{Journal of Quality in Health Care \& Economics}

6. Taylor R (2000) KM: The Management Process of Ensuring That the Organization's Existing Knowledge Assets pp: 1-5.

7. Carneiro A (2000) How does knowledge management influence innovation and competitiveness? Journal of Knowledge Management 4(2): 87-98.

8. Bjerre M, Sharma DD (2003) Is marketing knowledge international? A case of key accounts. In: Blomstermo A, Sharma DD, et al. (Eds.), Learning in the Internationalisation Process of Firms, Edward Elgar, Cheltenham pp: 123-141.

9. Baker, Michael J (2000) Marketing Strategy and Management. $3^{\text {rd }}$ (Edn.), Macmillan business, London.

10. Hanvanich S, Cornelia D, Calantone R (2003) Re conceptualizing the meaning and domain of marketing knowledge. Journal of Knowledge Management 7(4): 124-135.

11. Malhotra NK (2004) Marketing research. New Jersey: Prentice Hall.

12. Michael E porter (1990) The competitive advantage of National. HBR 68(2).

13. Morgan N, Clark B, Gooner R (2002) Marketing productivity, marketing audits, and systems for marketing performance assessment integrating multiple perspectives. Journal of Business Research 55: 363-375.

14. Tsai M, Shih C (2004) The impact of marketing knowledge among managers on marketing capabilities and business performance. International Journal of Management 21(4): 524-530. 